\title{
PARTIAL REPLACEMENT OF FISHMEAL BY ANIMAL PROTEIN WITH SUPPLEMENT OF DIETS IN FRESHWATER FISH Rasbora daniconius (Hamilton, 1822) AND Puntius ticto (Hamilton, 1822)
}

\author{
Encily Reymend Martin*, Sidharth D. Pagare \\ Department of Zoology, Dr. Babasaheb Ambedkar Marathwada University, Aurangabad-431 004. \\ Maharashtra, India
}

${ }^{*}$ Corresponding author
Phone:+919420345020
E-mail: martin_encily@yahoo.com

\begin{abstract}
The aim of this study was to evaluate the effects of two diets, artificial fish feed (Diet I) and animal protein (Diet II) as fish meals. These diets were fed to two different groups of fishes, Puntius ticto and Rasbora daniconius. During the experiment the survival rates were 100\%. Diet II mainly contained mollusc protein compared to Diet I. The growth performances were studied after feeding Diet I and Diet II for 25 days. At every $5^{\text {th }}$ day of feed intake, feed conversion ratio, gross feed conversion efficiency, growth coefficient of body weight and total length were studied. We found no significant increase in Diet II for the mentioned factors. The specific growth rate, percentage of body weight and total length increase showed a statistically significant increase.
\end{abstract}

Key words: Ticto barb, Slender rasbora, feed intake, feed conversion ratio, gross feed conversion efficiency, specific growth rate.

\section{INTRODUCTION}

Fish food consists of natural and artificial (supplementary) feeds. Sometimes, natural food may not be available in sufficient quantities. During such periods, foods manufactured or grown outside fish pond can be fed at regular interval. The feed supplements may not be nutritionally complete and may not support fish growth. Natural food in the water provides essential nutrients and in the absence of natural foods, all essential nutrients must be fed to fish. Artificial feeds are well-compounded mixtures of feedstuffs which can be in the form of mash or pellets, suitable for fish feeding. Mash feeds are good for fries and pellets $(0.8-1 \mathrm{~mm})$ for fingerlings, juveniles $(2-3 \mathrm{~mm})$, adults $(4-5 \mathrm{~mm}) \mathrm{de}-$ pending on pellet sizes. The use of artificial feeds is costly, but they have advantages in that they promote faster growth of fish. Increased usage of pellet feeds in carp culture is a necessity to increase the production and fish quality. This is especially important when the human nutritional value of the carp flesh is intended to be increased (Csengeri et al., 2013).

In the diet formulation for fish, the protein finds the upper hand as the most important proximate component in the diet. The overall digestion coefficient of the diet depends on the availability of quality protein source. The incorporation of protein in the formulated diets should be in optimum ratio with the energy components present therein. The protein component should consist of all the essential amino acids (Cho and Kaushik, 1985). The energy content in the diet varies according to the size of the fish species and on the amount of carbohydrate content (Cho and Kaushik, 1990). The fatty acid content also va- 
ries linearly with it. The vitamin and mineral composition should be in conjunction with the major proximate principles present in the aqua feed.

The cost of feed represents an important proportion of aquaculture operational costs. Protein sources are the major contributors to aquaculture feed costs (Sajed et al., 2014). Fish meal is the preferred dietary protein source for many farmed fish and shrimp species because of its amino acid balance, vitamin content, palatability and unidentified growth factors (Majumdar et al., 2014). However, fluctuating supplies and significantly elevating prices during the last decade encouraged the search for fish meal alternatives from different plant and animal sources. Plant materials suffer from low digestibility, high fibre content and antinutritional factors which limit their efficient use in aquaculture feeds (Francis et al., 2001).

The objective of the present study was to investigate the effect of different feeding rates with a diet containing appropriate protein on growth performance and food utilization. Fish meal (FM) is considered the most desirable animal protein ingredient. It constitutes a nutritionally complete diet for fish and crustaceans, due to its high protein content and digestibility as well as palatability, thus serves as an excellent source of essential fatty acids and energy.

\section{MATERIAL AND METHODS}

The fish Puntius ticto (Hamilton, 1822) and Rasbora daniconus (Hamilton, 1822) were procured from Godavari River, near Kaigaon toka, Aurangabad Maharashtra, India. They were acclimated to laboratory conditions for two weeks before experimentation in glass aquarium. The fish were maintained in laboratory conditions, in natural day: light $(\mathrm{D}: \mathrm{L})$ cycle at $25 \pm 1{ }^{\circ} \mathrm{C}$. The water was changed daily. Water temperature was maintained at $25 \pm 1{ }^{\circ} \mathrm{C}$. Dissolved oxygen was between 6.54-9.83 $\mathrm{mg} / \mathrm{L}$. The $P$. ticto fish of average weight $15 \pm 0.1 \mathrm{~g}$ and length $7.36 \pm 0.19 \mathrm{~cm}$ and $R$. daniconius of average weight $17.4 \pm 0.15 \mathrm{~g}$ and length of $6.8 \pm 015 \mathrm{~cm}$ was used for the present study.
The growth experiment was conducted on acclimated fish. Both $P$. ticto and $R$. daniconius were taken and their length and weight was measured individually. After that, 10 fish of both types were placed in different aquariums such as that two aquariums for $P$. ticto (Group I) and two for $R$. daniconus (Group II) were fed with Artificial Fish Food (AFF) (Diet I) and other Animal Feed Protein (AFP) (Diet II) respectively for both fishes. Four grams of Diet I and Diet II were given to each aquarium on the first day, thereafter on every $5^{\text {th }}$ day till the $25^{\text {th }}$ day. On every $5^{\text {th }}$ day, the length and weight of the fish were recorded.

\section{Chemical analysis}

Proximate analysis of Diet I and Diet II were carried out by drying the feed in a crucible at $100{ }^{\circ} \mathrm{C}$ in a laboratory oven. After drying the diet, the diets were grinded in a mixer and again dried. The dried powder was used for the analysis. Chemical composition (moisture, fat, ash, crude fiber, proteins, carbohydrates by difference) and caloric value of Diet I and Diet II were analyzed according to the methods as described by AOCS (1992).

\section{Protein intakes (PI)}

This is the product of feed supplied and the percentage of crude protein present in the feed. This was calculated, according to the methods as described by Teugels (1984). This is given by the following formula:

Daily feed intake $(\%)=\frac{\text { Feed intake }(g \text { drymatter }) \times 100}{\frac{\text { Final fish weight }(g)+\ln \text { intial f fish weight }(g)}{2} \times \text { Feed days }}$

\section{Feed conversion ratio (FCR)}

The FCR values were calculated by the formula:

$F C R=\frac{\text { Weight of the feed supplied }}{\text { Weight of the fish }- \text { Weight of the feed supplied }}$

\section{Gross feed conversion efficiency (GFCE) (\%)}

This is the reciprocal of feed conversion ratio (FCR). This is given by formula: 


$$
\mathrm{GFCE}=\frac{1}{\mathrm{FCR}} \times 100
$$

\section{Specific growth rate (\%) per day (SGR)}

This was calculated by using following formula:

$$
\operatorname{SGR}(\%) \text { per day }=\frac{\ln (\text { Final fish weight })-\ln (\text { Initial fish weight })}{\text { Number of days fish were fed }} \times 100
$$

\section{Growth coefficient}

Growth coefficient is determined by the formula as described by Everhart et al., (1975):

$$
\mathrm{g}=\ln \frac{\mathrm{w}_{\mathrm{t}}}{\mathrm{w}_{0}}
$$

where $I n$ is the natural logarithm and $w_{t}$ and $\mathrm{w}_{\mathrm{o}}$ are as before (Everhart, et al., 1975).

\section{Statistical analysis}

The data were subjected to statistical analysis, using ANOVA and post-hoc Tukey's test at significance level 0.05 .

\section{RESULTS}

\section{Proximate composition of diet ingredients}

The proximate compositions for fish Diet I and Diet II were found to be fairly close except that the protein content for Diet II was $34.1 \%$ and for Diet I was $14.1 \%$. The carbohydrate dry difference was higher for Diet I (67.5\%) than for Diet II (43.9\%). The values of proximate analysis are given inTable 1.

\section{Feed intake}

The daily feed intake, specific growth rate and feed conversion ratio of $P$. ticto and $R$. daniconius are shown in Figure 1. Feed intake showed a similar pattern in both fish fed with Diet I and Diet II. The daily feed intake of the Group I fish showed no statistically significant difference in feed intake to Diet I and Diet II. Similarly, Group II fish also showed no statistical significant changes in feed intake.

\section{The feed conversion ratio (FCR)}

The feed conversion ratio for $P$. ticto and $R$. daniconius for Diet I and Diet II is shown in Figure 2. The study showed less FCR for Diet I compared to Diet II. However, FCR showed no statistically significant difference between the two diets in Group I fish. Similarly, FCR for Group II fish also showed no statistically significant difference.

\section{The specific growth rate}

The specific growth rate studies of $P$. ticto and R. daniconius to Diet I and Diet II are shown in Figure 3. The specific growth rate for $P$. ticto for two different diets showed a significant statistical change. In $R$. daniconius, however, both diets showed no statistical significant changes indicating that Diets I and II had no significant effect on R. daniconius.

Table 1.

Proximate analysis of fish feed Diet I (Artificial fish Feed) and Diet II (Animal Protein Feed)

\begin{tabular}{lccc}
\hline No. & $\begin{array}{c}\text { Parameters } \\
(\%)\end{array}$ & Diet I & Diet II \\
\hline 1. & Moisture & 5.1 & 6.6 \\
2. & Fat & 2.5 & 4.2 \\
3. & Ash & 4.1 & 11.1 \\
4. & Crude fiber & 6.7 & 0.1 \\
5. & Protein & 14.1 & 34.1 \\
6. & Carbohydrates (by difference) & 67.5 & 43.9 \\
7. & Caloric value (kcal/100g) & 349 & 349.8 \\
\hline
\end{tabular}




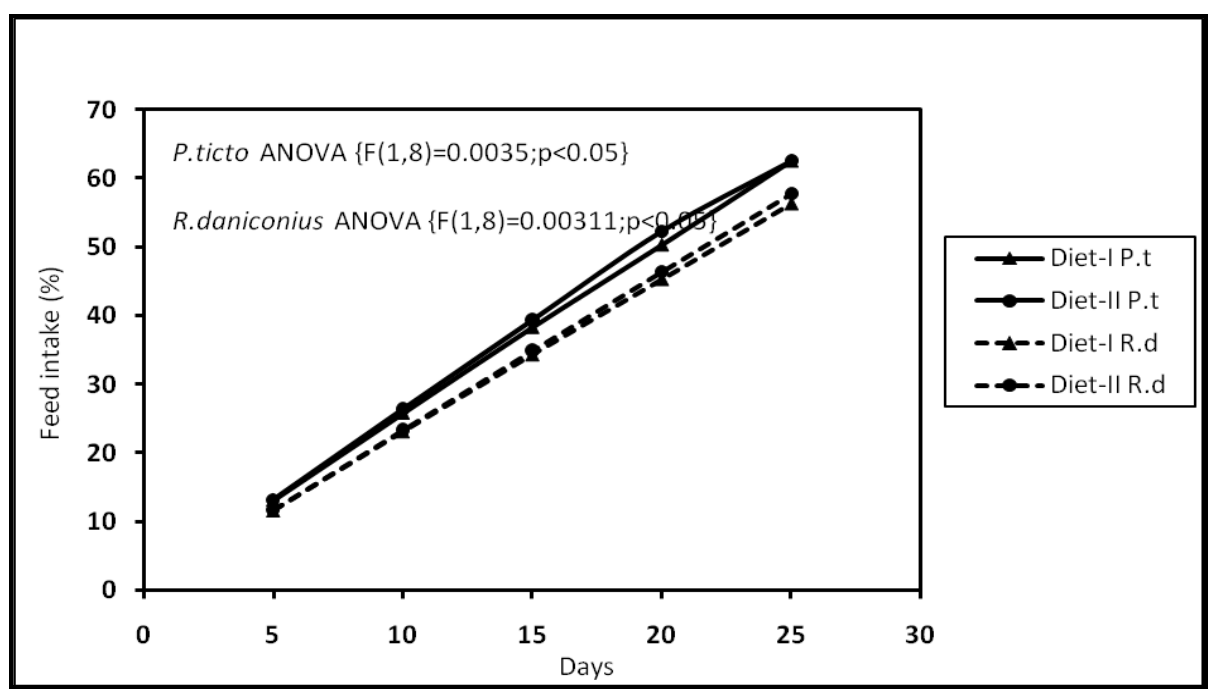

Figure 1. Feed intake of $P$. ticto and $R$. daniconius

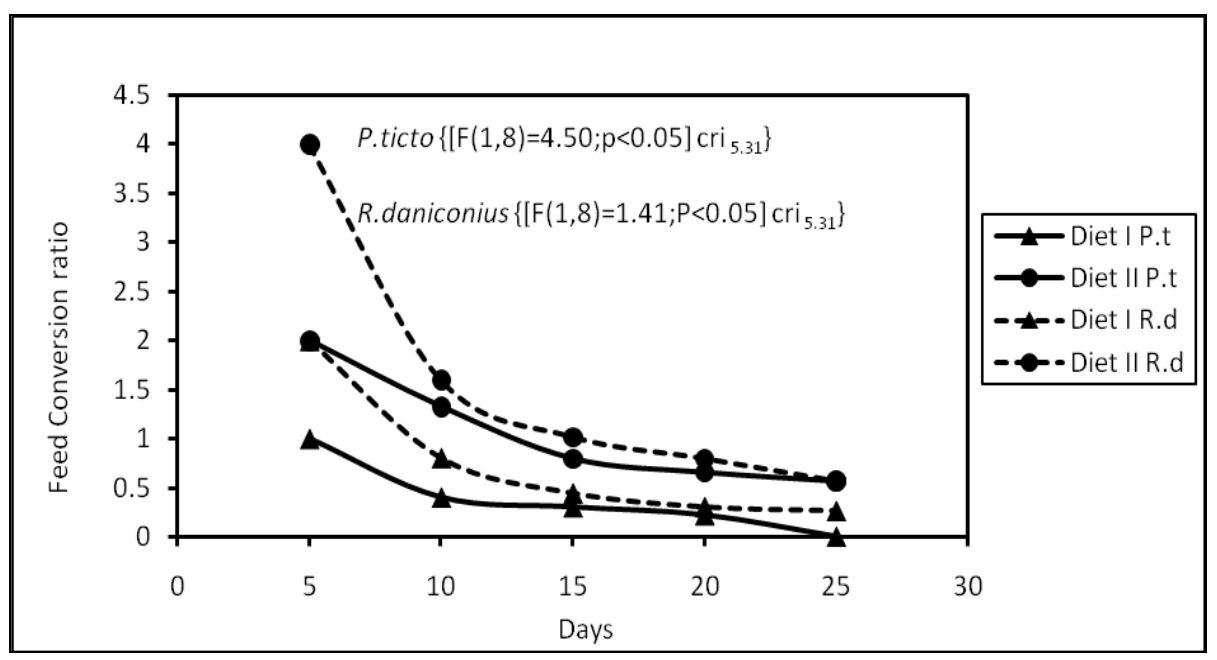

Figure 2. Feed conversion ratio in $P$. ticto and $R$. daniconius

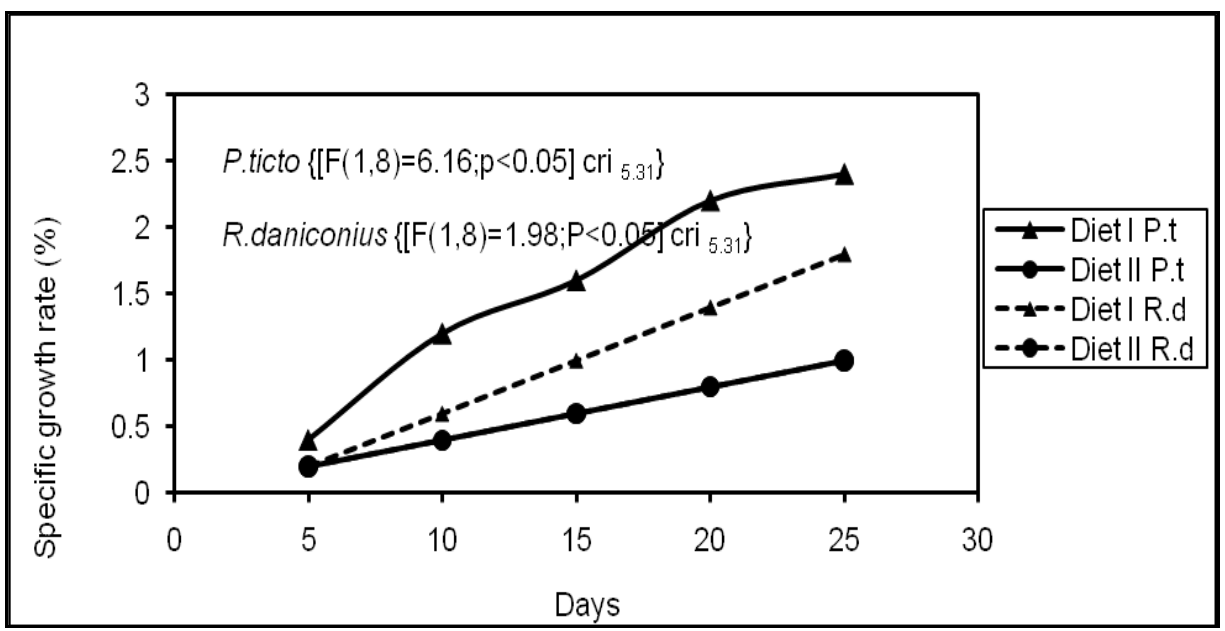

Figure 3.Specific growth rate of $P$. ticto and $R$. daniconius 


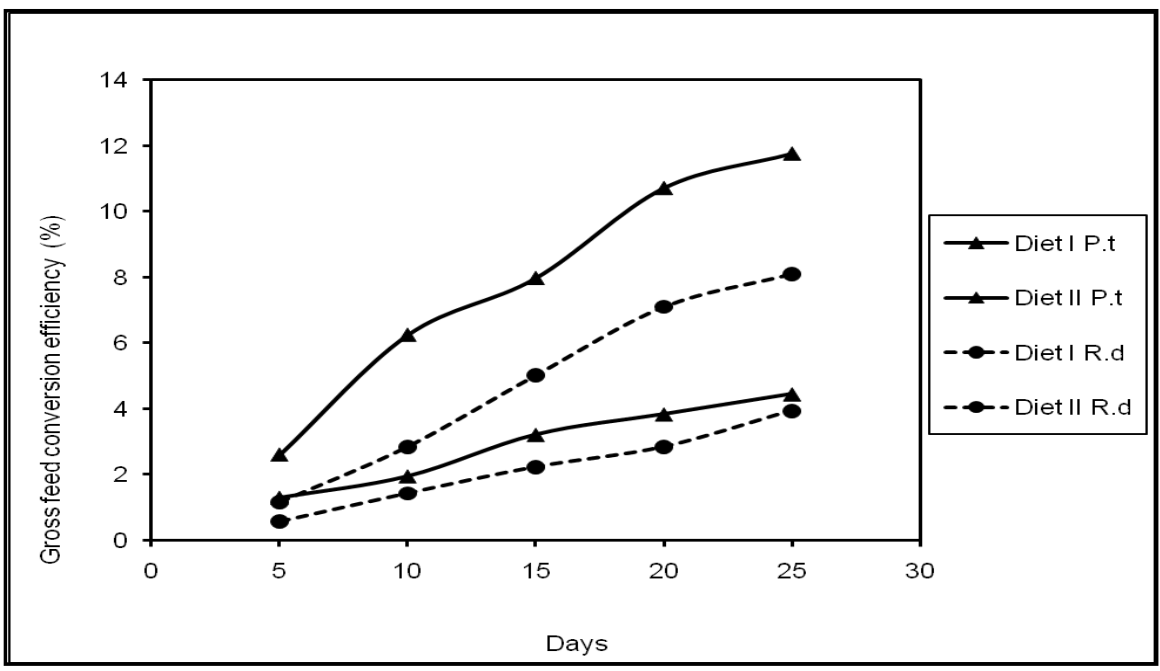

Figure 4. Gross feed conversion efficiency ratio (\%) in $P$. ticto and $R$. daniconius

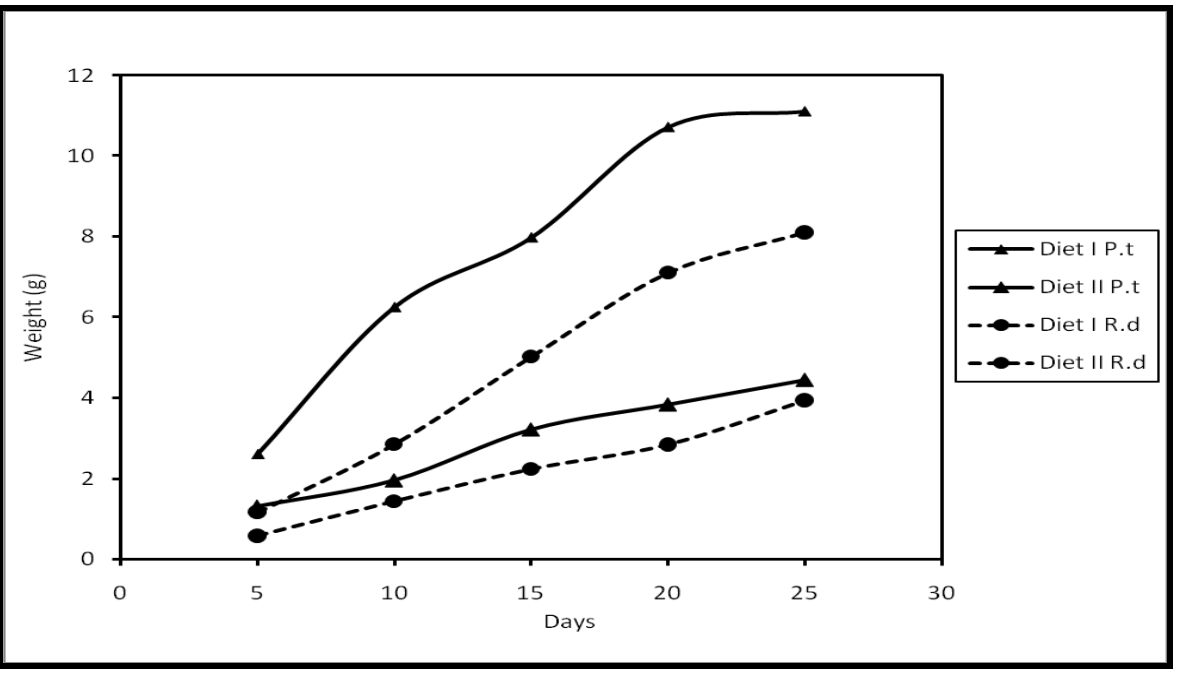

Figure 5. Growth coefficient of body weight for P. ticto and R. daniconius

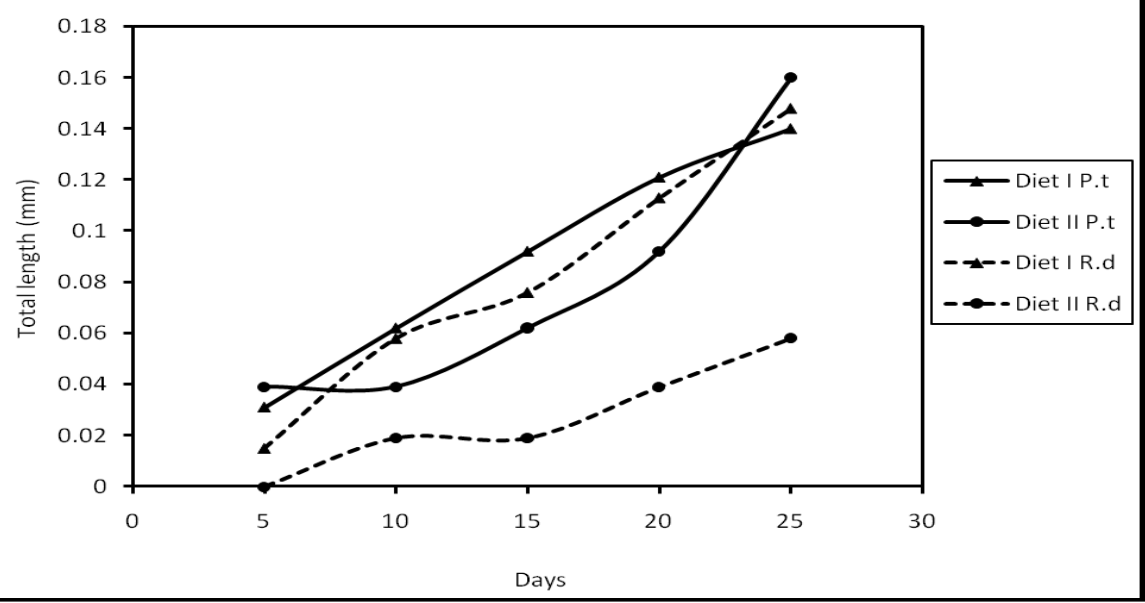

Figure 6. Growth coefficient of total length for $P$. ticto and $R$. daniconius 


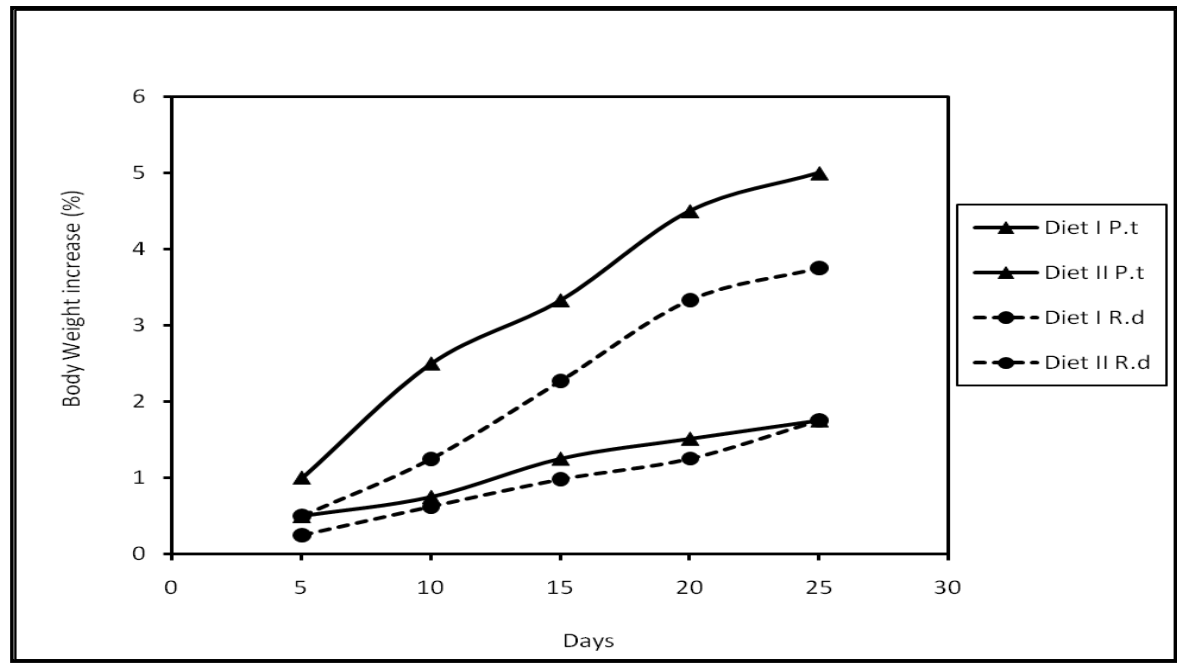

Figure 7. Percentage of body weight increase for P. ticto and $R$. daniconius

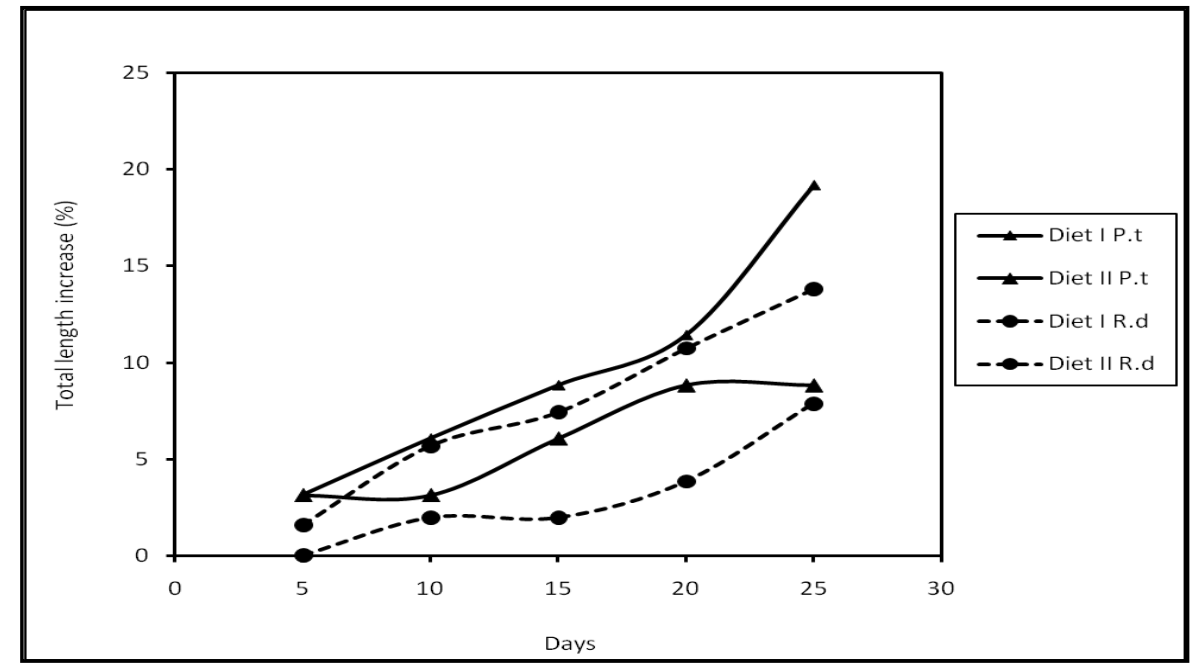

Figure 8. Percentage of total length increase for P. ticto and R. daniconius

\section{Gross feed conversion efficiency (GFCE)}

The gross feed conversion efficiency (GFCE) for $P$. ticto and $R$. daniconius is shown in Figure 4. The GFCE showed a statistically significant increase in $P$. ticto for Diet I and Diet II. However, the GFCE for $R$. daniconius showed no statistically significant $(\mathrm{P}<0.05)$ difference between Diet I and Diet II.

\section{Growth coefficient}

Body weight and total length of $P$. ticto and $R$. daniconius are shown in Figures 5 and 6 , respectively. The body weight in Group I fish showed a significant increase for Diet I and Diet II. However, Group II fish showed no statistically significant increase with both diets. The total length increase to both diets showed no statistically significant difference for Group I and Group II fish, respectively.

\section{Percentage increase in body weight and total length to diets}

The percentage increase in body weight and total length for Group I and Group II fish are shown in Figures 7 and 8, respectively. The body weight in Group I showed a significant increase between Diet I and Diet II. However, Group II fish showed no statistically significant differ- 
rence between both diets. The total length increase in both diets showed no statistical significant difference for Group I and Group II fish.

\section{DISCUSSION}

Studies on the growth of fish supplemented by alternative sources of feed with a view to find an alternate source of fish feed in aquaculture have been carried out by various workers over the world (Hartviksen et al., 2014; Ljubojevic et al., 2015; De Santis et al., 2015). The lesser known fish, which are not a major carp, are eaten by poor people, however, with the push in aquaculture this fish has been recognized as a valuable source of protein.

In the present study, a linear relationship of food intake was observed in P. ticto and $R$. daniconius with Diet I and II. The FCR was less for Diet I compared to Diet II, though, no statistical significant changes were observed. The body weight, length, FCR, specific growth, growth coefficient (weight, length), all showed an increase in both fish, but Diet I caused a higher increase compared to Diet II.

The reduced growth with Diet II could be due to an increased protein in Diet II compared to Diet I. There are reports showing that higher proteins slow growth rate which may be due to low digestibility, poor protein and amino acid utilization or some unknown factors could reduce the growth of fish (Beeker and Makkar, 1999). Saeed et al. (2005) reported a low growth rate in Labeo rohita, provided with soya bean meal to corn glutens protein. Similar observations were reported by other workers (Rajbanshi, 1989; Salim and Sheri, 1999).

Dabrowski (1977) reported that gram carp fry requires $45.6 \%$ protein. Similarly, dietary protein requirement of $40 \%$ and above have been reported by various workers, which increased weight gain and SGR (Diyaware et al., 2010; Sawhney and Gandotre, 2010).

Siddiqui et al. (1988) and AlHafed (1999) reported that decrease in feed conversion ratio is due to an increase in proteins. The present study also showed that lower protein level resulted in higher feed conversion ratio and growth level. The proteins in both diets (Diet I and Diet II) were different, Diet I contained $14.1 \%$ and Diet II contained $34.1 \%$ proteins. The study indicated that in fish $P$. ticto and $R$. daniconius high protein may not be helpful for growth. The present results are in contrast to the reports of Sawhnay and Gandotre (2010) and Diyaware et al. (2010). However, Diet II can be improved with low formulated animal protein source, which may increase FCR and facilitate better growth in this species of fish. Nutritional absorption and growth need further investigation when applying animal protein sources in the diet. The present finding is comparable to other studies in that high protein feed in fact decrease the feed conversion ratio.

Information on feed consumption pattern is necessary to achieve an optimized feeding regime for particular fish species (Wang et al., 1998). In the present study, the daily feed consumption patterns of both fish were similar. Growth parameters of fish in this experiment compares well with previous studies of Gumus et al. (2009).

The differences within the results of the current study may be ascribed to the lower energy content. Takeuchi et al. (2002) demonstrated that energy content and thus $\mathrm{P} / \mathrm{E}$ ratio, in common carp diets are determinant factors that govern feeding and growth efficiency especially during the early life stages and diets must be designed carefully to satisfy the optimum levels of these components.

Davies and Gouveia (2010) studied the response of common carp fry fed diets containing a pea seed meal (Pisum sativum); the reported SGR values relatively coincided with the results of the present study. Several researchers indicated that younger fish have higher growth rates, animal protein sources are better performed as feed ingredients than plant proteins and fish stocking density is correlated inversely with fish growth (Wilson, 2002; Jha and Barat, 2005; Dumas et al., 2010).

The enhanced growth and feeding rates in fish showed an increased feeding frequency which was shown by several workers (Ruohonen et al., 1998; Wang et 
al., 2007). However, there are few reports that feeding frequency did not affect size variation (Kucuk et al., 2013; Sung-Yong and Venmathi, 2015).

Improvements in weight gain and feed efficiency have been reported for juvenile channel catfish raised in aquaria and fed with diets containing menhaden fish meal levels up to $20 \%$ (Mohsen and Lovell, 1990 ) or $30 \%$ (Andrews and Page, 1974). Although growth and FE improvement achieved by supplementing high levels of fish meal in the diet in those studies might partially be related to the high energy or fat content contributed by fish meal, improvement by the addition of low levels of fish meal might not be explained by the slight increase in energy or fat concentrations. Mohsen and Lovell (1990) found that channel catfish fed diets containing 5$10 \%$ fish meal had significantly greater weight gain and FE than fish fed a basal diet without fish meal and that supplementing catfish oil to the basal diet did not improve fish performance.

\section{CONCLUSIONS}

It can be concluded that animal feed protein have potential in aquaculture. It is being used for major carp. Protein content of $45 \%$ and higher is shown to increase the growth of carps. However, in the present study, the growth with Diet II (34.1\% protein) was less than that with Diet I (14.1\% protein). The increased protein, especially, from Diet II protein induced a lesser growth compared to Diet I. However, by manipulating the Diet II protein an increase in growth can be achieved.

\section{ACKNOWLEDGEMENTS}

Authors are thankful to the Head Department of Zoology, Dr. Babasaheb Ambedkar Marathwada University, Aurangabad, Maharashtra, India. Authors are thankful to anonymous reviewers for their critical evaluation and suggestions.

\section{REFERENCES}

1. AlHafedh, Y.S. (1999). Effects of dietary protein on growth and body composition of Nile tilapia, Oreochromis niloticus L. Aquatic Research, 30, 385-393.

2. AOCS (1992). Official Methods and Recommended Practices, $4^{\text {th }}$ edition, AOCS. Cham- paign, Illinois. USA.

3. Atanasoff, A.P. (2014). Replacement of fish meal by ribitricin in diets of carp Cyprinus carpio. Mace Veterinary Review, 37 (1), 55-59.

4. Becker, K., Makkar, H.P.S. (1999). Effects of dietary tannic acid and quebracho tannin on growth performance and metabolic rates of common carp (Cyprinus carpio L.). Aquaculture, 175, 327-335.

5. Cho, C.Y., Kaushik, S.J. (1985). Effects of protein intake on metabolizable and net energy values of fish diets. In Nutrition and Feeding in Fish. Eds. C.B. Cowey, A.M. Mackie, J.G. Bell, Academic Press, London, pp. 95-117.

6. Cho, C.Y., Kaushik, S.J. (1990). Nutritional energetic in fish: Energy and protein utilization in rainbow trout (Salmo gairdneri). World Review of Nutrition and Dietetics, 61, 132-172.

7. Csengeri, I., Čolović, D., Rónyai, A., Jovanović, R., Péter-Szűcsné, J., Sándor, Zs., Gyimes, E. (2013). Feeding of common carp on floating feeds for enrichment of fish with es-sential fatty acids. Food and Feed Research, 40 (2), 59-70.

8. Dabrowski, K. (1977). Protein requirement of grass carp fry (Ctenopharyngodon Idella Val.). Aquaculture, 12, 63-73.

9. De Santis, C., Ruohonen, K., Tocher, D.R., Martin, S.A.M., Krol, E., Secombes, C.J., Bell, J.G., El-Mowafi, A., Crampton, V.O. (2015). Atlantic salmon (Salmo salar) parr as a model to predict the optimum inclusion of air classified faba bean protein concentrate in feeds for seawater salmon. Aquaculture, 444, 70-78

10. Davies, S.J., Gouveia, A. (2010). Response of common carp fry fed diets containing a pea seed meal (Pisum sativum) subjected to different thermal processing methods. Aquaculture, 305, 117-123.

11. Diyaware, M.Y., Haruna, A.B., Abubakar, K.A. (2010). Growth and survival of hybrid fingerlings of Clarias anguillaris and Heterobranchus bidorsalis in North East Nigeria. Journal of Arid Agriculture, 19, 24-30.

12. Dumas, A., France, J., Bureau, D. (2010). Modelling growth and body composition. Aquaculture Research, 41, 161-181.

13. Everhart, W.H., Eiper, A.W., Youngs, W.D. (1975). Principles of Fishery Science, Cornel University Press, New York.

14. Francis, G., Makkar, H.P.S., Becker, K. (2001). Antinutritional factors present in plant-derived alternate fish feed ingredients and their effects in fish. Aquaculture, 199, 197-227.

15. Hartviksen, M., Vecino, J.G., Ringo, E., Bakke, A.M., Wadsworth, S., Krogdahl, A., Ruohonen, K., Kettunen, A. (2014). Alternative dietary protein sources for Atlantic Salmon (Salmo salar L.) effect on intestinal microbiota intestinal and liver histology and growth. Aquaculture Nutrition, 20, 381-398.

16. Gumus, E., Kaya, Y., Balci, B. A., Acar, B.B. (2009). Partial replacement of fishmeal with tuna liver meal in diets for common carp fry, 
Cyprinus carpio L. 1758. Pakistan Veterinary Journal, 29 (4), 154-160.

17. Hamilton, F. (1822). An Account of the Fishes Found in the River Ganges and its Branches, Archibald, Constable \& Co., Edinburgh Hurst, Robinson \& Co., London.

18. Jain, A.K., Kumar, G., Mukherjee, S.C. (2006). Survival and growth of early juveniles of barramundi, Lates calcarifer (Bloch, 1790) in inland saline groundwater. Journal of Biological Research, 5, 93-97.

19. Jha, P., Barat, S. (2005). The effect of stocking density on growth, survival rate, and number of marketable fish produced of koi carps, Сyprinus carpio var. koi, in concrete tanks. Journal of Applied Aquaculture, 17, 89-102.

20. Kucuk, E., Aydin, I., Polat, H., Eroldogan, O.T., Sahin, T. (2013). Effect of feeding frequency on growth, feed efficiency and nutrient utilization of juvenile flounder (Platichthys flesus luscus). Aquaculture International, 22, 723-732.

21. Ljubojevic, D., Radosavljevic, V., Puvaca, N., Balos, M.Z., Dordevic, V., Jovanovic, R., Cirkovic, M. (2015). Interactive effects of dietary protein level and oil source on proximate composition and fatty acid composition in common carp (Cyprinius carpio L.). Journal of Food Composition and Analysis, 37, 44-50.

22. Majumdar, R.K., Deb, S., Nath, K.B. (2014). Effect of co-dried silage from fish market waste as substitute for fish meal on the growth of the Indian major carp Labeo rohita (Hamilton, 1822) fingerlings. Indian Journal of Fishery, 61 (4), 63-68.

23. Rahman, M.M., Jo, Q., Gong, Y.G., Miller, S. A., Hossain, M.Y. (2008). A comparative study of common carp (Cyprinus carpio L.) and calbasu (Labeo calbasu Hamilton) on bottom soil resuspension, water quality, nutrient accumulations, food intake and growth of fish in simulated rohu (Labeo rohita Hamilton) ponds. Aquaculture, 285, 78-83.

24. Rajbanshi, V.K., Mumtazuddin, M., Shim, K.F. (1989). Reciprocation of dietary protein with growth and its utilization in rohu, Labeo rohita (Ham.) fingerlings. Singapore Journal of Primary Industries, 17 (2), 128-131.

25. Ruohonen, K., Vielma, J., Grove, D.J. (1998). Effects of feeding frequency on growth and food utilization of rainbow trout (Oncorhynchus mykiss) fed low-fat herring or dry pellets. Aquaculture, 165, 111-121.

26. Saeed, M., Salim, M., Noreen, U. (2005). Study on the growth performance and feed con- version ratio of Labeo rohita fed on soybean meal, blood meal and corn gluten $60 \%$. Pakistan Veterinary Journal, 25, 121-126.

27. Sajed, S.A., Basmin, M.J., Salah, M. N. (2014). Feeding and growth efficiency of common carp Cyprinus carpio L. Fry fed bio silage as a partial alternative for fish meal. Global Journal of Biology, Agriculture and Health Sciences, 3 (2), 81-85.

28. Salim, M. and A.N. Sheri, 1999. Influence of protein sources, levels of protein and levels of feeding on growth of rohu (Labeo rohita) fingerlings under intensive Pakistan Journal of Scientific Research, 51, 85-8.

29. Sawhney, S., Gandotre R. (2010). Growth response and Feed Conversion Efficiency of Tor putitor a (Ham.) Fry at Varying Dietary Protein Levels. Pakistan Journal of Nutrition, 9, 86-90.

30. Siddiqui, A.Q., Howlader, M.S., Adam, A.A. (1988). Effect of dietary protein levels on growth, feed conversion and protein utilization in fry and young Nile tilapia Oreochromis niloticus. Aquaculture, 70, 63-73.

31. Singh, B.N., Sinha, V.R.P., Kumar, K. (1987). Protein requirement of an Indian major carp, Cirrhinus mrigala (Ham.) International Journal of Academic Ichthyology, 8, 71-75.

32. Sung-Yong, O., Venmathi Maran, B.A. (2015). Feeding frequency influences growth, feed consumption and body composition of juvenile rock bream (Oplegnathus fasciatus). Aquaculture International, 23, 175-184.

33. Takeuchi, T., Satoh, S., Kiron, V. (2002). Common carp, Cyprinus carpio. In Nutrient requirements and feeding of finfish for aquaculture. Eds. C.D., Webster, C. Lim, CABI Pub. Silver Springs, FL, pp. 245-261.

34. Teugels, S.G.G. (1984). The nomenclature Agric Clarias species used in aquaculture. Aquaculture, 38, 373-374.

35. Wang, N., Hayward, R.S., Noltie, D.B. (1998). Effect of feeding frequency on food consumption, growth, size variation, and feeding pattern of age-0 hybrid sunfish. Aquaculture, 165, 261-267.

36. Wang, Y., Kong, L., Li, K., Bureau, D.P. (2007). Effects of feeding frequency and ration level on growth, feed utilization and nitrogen waste output of cuneate drum (Nibea miichthioides) reared in net pens. Aquaculture, 271, 350-356.

37. Wilson, R.P. (2002). Amino acids and proteins. In Fish Nutrition, $3^{\text {rd }}$ edition. Eds. J.E. Halver, R.W. Hardy, Academic Press, Orlando, pp.144179. 


\title{
ДЕЛИМИЧНА СУПЛЕМЕНТАЦИЈА ХРАНЕ ЗА РИБЕ ПРОТЕИНИМА ЖИВОТИЊСКОГ ПОРЕКЛА У ИСХРАНИ СЛАТКОВОДНИХ РИБА Rasbora daniconius (Hamilton, 1822) И Puntius ticto (Hamilton, 1822)
}

\author{
Encily Reymend Martin*, Sidharth D. Pagare
}

Department of Zoology, Dr. Babasaheb Ambedkar Marathwada University, Aurangabad-431 004.

Maharashtra, India

\begin{abstract}
Сажетак: Циљ овог рада је оцењивање ефеката две формулације хране за рибе, и то вештачке хране за рибе (Храна I) и протеина животињског порекла (Храна II). Две групе различитих риба, Puntius ticto и Rasbora daniconius, храњене су наведеном храном. Током експеримента, удели преживљавања риба су износили $100 \%$. Храна 2 је претежно садржавала протеине мекушаца. Параметри раста риба праћени су током 25-дневне исхране риба наведеним формулацијама. Сваког петог дана експеримента, праћени су следећи параметри: усвајање хранива, степен конверзије хранива, укупна ефикасност конверзије хранива, коефрицијент раста телесне масе и дужине риба. Није запажен значајан раст ових параметара приликом исхране риба Храном II. Запажено је статистички значајано побољшање у погледу специфичне брзине раста као и процента повећања телесне масе и дужине риба.
\end{abstract}

Кључне речи: Ticto barb, Slender rasbora,yсвајање хранива, степен конверзије хранива, укупна ефикасност конверзије хранива, специфична брзина раста

Received: 20 August 2015

Accepted: 12 February 2016 